\title{
1 Loss and recovery of carbon and nitrogen after mangrove
}

\section{2 clearing}

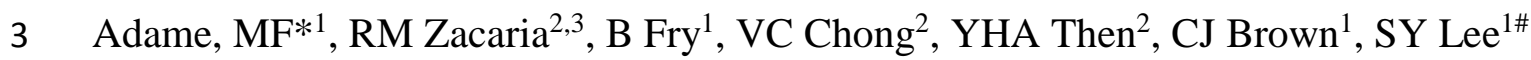

$4 \quad{ }^{1}$ Australian Rivers Institute, Griffith University, Nathan, QLD, Australia 4111

$5 \quad{ }^{2}$ Institute of Biological Sciences, University of Malaya, Kuala Lumpur, Malaysia, 50603

$6{ }^{3}$ Institute of Ocean and Earth Sciences, University of Malaya, Kuala Lumpur, Malaysia, 50603

$7 \quad$ \# present address: Simon F S Li Marine Science Laboratory, School of Life Sciences, and Earth System Science

8 Programme, The Chinese University of Hong Kong, Shatin, Hong Kong SAR, China

9 *Correspondence to: Fernanda Adame (f.adame@griffith.edu.au)

10

11

12

13

14

15

16

17

18

19 


\section{Abstract}

Offsetting carbon $(\mathrm{C})$ emissions and reducing nitrogen $(\mathrm{N})$ pollution have been goals of mangrove restoration programs around the world. There is a common, yet dubious expectation that mangrove restoration will result in immediate and perpetual delivery of ecosystem services. There are expected time lags between mangrove clearing and $\mathrm{C}$ and $\mathrm{N}$ losses, and between restoration and $\mathrm{C}$ and $\mathrm{N}$ gains. Obtaining accurate rates of losses and gains requires frequent and long-term sampling, which is expensive and time consuming. To address this knowledge gap, we used a chronosequence of mangrove forests in mangroves in Matang Mangrove Forest Reserve (MMFR) in Malaysia, a region with one of the most C dense forests in the world. In this site, we assessed the ecosystem $\mathrm{C}$ and $\mathrm{N}$ stocks, including soil, downed wood, downed litter, and trees. The objective was to measure $\mathrm{C}$ and $\mathrm{N}$ changes through time. After mangrove clearing, $\mathrm{C}$ and $\mathrm{N}$ losses in soil and downed wood were rapid, with stocks halved after just one year. In the first 10 years after replantation, the forest recovered quickly, with rates of $\mathrm{C}$ accumulation of $9.5 \mathrm{Mg} \mathrm{C} \mathrm{ha}^{-1} \mathrm{yr}^{-1}$. After ten years, the rate of accumulation decreased to $2.8 \mathrm{Mg} \mathrm{C} \mathrm{ha}^{-1} \mathrm{yr}^{-1}$. However, 40 years after replantation, mangroves were still about $26 \%$ lower in $\mathrm{C}$ and $15 \%$ lower in $\mathrm{N}$ compared to our reference forest. The trajectory of recovery of $\mathrm{C}$ and $\mathrm{N}$ stocks in these forests was different among mangrove components: forest litter recovered rapidly, but downed wood and soil recovered much slower. Programs aimed at reducing $\mathrm{C}$ emissions and $\mathrm{N}$ pollution should consider that there are temporal lags and ecosystem trade-offs when assessing the effectiveness of mangrove protection and restoration as climate change mitigation strategies. 


\section{Introduction}

Mangrove forests are considered key ecosystems in mitigation programs aimed at reductions in carbon (C) emissions (Murdiyarso et al., 2015) and nitrogen $(\mathrm{N})$ pollution (Mitsch \& Gosselink, 2015). Mangrove forests sequester more $\mathrm{C}$ and $\mathrm{N}$ per area than most terrestrial ecosystems (Donato et al., 2011; Adame et al., 2015a). Contrary to terrestrial forests, mangroves store the majority of their $\mathrm{C}$ and $\mathrm{N}$ not as plant biomass, but in the soil, where stocks can remain stable for centuries (Adame and Fry, 2016). Mangrove deforestation results in changes in $\mathrm{C}$ and $\mathrm{N}$ fluxes to the coast (Lee, 2016) and the release of large amounts of $\mathrm{C}$ (Alongi et al., 1998; Lovelock et al., 2011). Mangrove restoration has the potential to offset these $\mathrm{C}$ and $\mathrm{N}$ losses (Alongi, 2012; Ouyang \& Guo, 2016).

Throughout the world, numerous mangrove restoration programs are underway, including Mexico (Zaldívar-Jiménez et al., 2010), U.S.A. (Lewis, 2001), East Africa (Kairo et al., 2001), Sri Lanka (Kodikara et al., 2017), and the Philippines (Walton et al., 2007). The expectation of these programs is to restore ecosystem services (Lee et al., 2014; Adame et al., 2015b). Restoration goals include increased coastal protection (Kodikara et al., 2017), pollution reduction (Ouyang \& Guo, 2016), and C emission mitigation (Alongi, 2012). The success of restoration programs is usually assessed, if at all, as the establishment of mangrove seedlings after planting (Ellison, 2000; Kodikara et al., 2017). However, even when established, juvenile mangroves might not immediately provide the expected ecosystem services (Koch et al., 2009). In order to assess the success of restoration programs, it is important to consider time lags between perturbation, restoration, and return of ecosystem services. 
Loss of $\mathrm{C}$ and $\mathrm{N}$ is likely to occur within the first years after perturbation, while

67

68 sequestration occurs within the scale of decades (Marchand, 2017). To assess loss and recovery rates of $\mathrm{C}$ and $\mathrm{N}$, frequent and long-term sampling is required, which is expensive and time consuming. The lack of adequate data obtained within realistic time frames constrains the capacity of mangroves to participate in $\mathrm{C}$ and $\mathrm{N}$ markets (Alongi, 2011) and creates false expectations that ecosystem services can be immediately and perpetually restored (Koch et al., 2009).

In this study, we sampled a chronosequence of mangroves in the managed forest of Matang Mangrove Forest Reserve (MMFR), Malaysia. The MMFR is the only mangrove forest in the world with a century-long history of managed forestry (Shaharuddin et al., 2005). The MMFR is managed for timber harvesting and comprises mangrove plots of various ages, from recently cleared plots to those that were never clear-cut and are almost a century-old. We took advantage of this setting to study how $\mathrm{C}$ and $\mathrm{N}$ in forest litter, downed wood and soil respond to perturbation, in this case clear-cut harvesting. We also collected published information on soil and tree $\mathrm{C}$ from previous studies in MMFR. The aim was to quantify the loss of $\mathrm{C}$ and $\mathrm{N}$ after mangrove clearing, the temporal trajectory of recovery, and the potential pathways of gains and losses. This information will provide a realistic time frame for the assessment of restoration success and the fair valuation of mangrove forests in ono of the most $\mathrm{C}$ dense regions in the world (Atwood et al. 2017).

\section{Materials and Methods}

\subsection{Study site}


E) on the northwest coast of Perak State, Peninsular Malaysia (Fig.1). The MMFR lies on MMFR has 40,288 ha of mangrove forests, from which $75 \%$ are managed for the production of charcoal and poles. The MMFR includes 569 ha of forest that has never been clear-cut, although had some isolated tree harvesting 70 years ago. This forests, hereafter "reference" forest, supports a high tree diversity. The MMFR also has an old-growth forest of $40+$ years set aside for education purposes.

Forests in MMFR are currently managed on a 30-year rotation cycle with 110 defined compartments or management units (Shaharuddin et al., 2005). Approximately 1,000 ha of mangroves are harvested annually. One to two years after tree harvest, the forest is replanted two monsoons, the southwest monsoon, which usually arrives in May and lasts until 
rainfall of the region is between $200-400 \mathrm{~mm}$ per month, with the months of October and

114 November being the wettest (Malaysian Meteorological Department, 2017). Annual mean

115 water temperature of the Sepetang River is relatively constant at $29^{\circ} \mathrm{C}$; $\mathrm{pH}$ values of the water range from 6.8 to 7.2 , and salinity ranges from $15.1 \pm 0.1$ upstream to $24.5 \pm 0.5$ in coastal waters (Ramarn et al., 2012). Tides are semi-diurnal, mesotidal, with mean high levels of $2.69 \mathrm{~m}$ and $2.06 \mathrm{~m}$ for spring and neap tides, respectively (NHCM, 2016).

\subsection{Site selection and sampling}

Field sampling was conducted in February 2016. A range of mangrove sites of different ages were sampled to assess changes in $\mathrm{C}$ and $\mathrm{N}$ stocks through time. The selected sites were close to each other $(<5 \mathrm{~km}$ apart $)$ and had similar salinity and nutrient inputs (Katsuhisa and Choo, 2000). The six sites ranged in age as follows: (1) one year after harvesting, hereafter "clear-cut "site (Block P-14-24 in compartment 19), (2) five years after replantation (Block P-10-119, compartment 31), (3) 15 years after replantation (Block P-00107, compartment 44), (4) 30 years after replantation (Block P-15-165, Compartment 19), (5) an old-growth forest of 40 years reserved for educational purposes (43 ha), and finally, (6) a 70 year-old reference forest (Fig. 1, Table 1). All forests fringed a main river channel, except the 40 year-old forest, which fringed a smaller creek (Reba River).

At each site, a 100m-transect perpendicular to the water edge was established following the methodology of Kauffman \& Donato (2012). This sampling design considers that the variation in mangrove structure and biomass is mainly driven by tidal inundation (Lugo and Snedaker 1992). Within each transect, we established six plots of $7 \mathrm{~m}$ in radius at $25 \mathrm{~m}$ intervals. In the clear-cut site, the intervals were $10 \mathrm{~m}$ because the cleared patch was < 
$100 \mathrm{~m}$ in width. At each plot, we collected samples to measure $\mathrm{C}$ and $\mathrm{N}$ in forest litter, downed wood, and soil as explained below.

\subsubsection{Forest litter}

Forest litter was collected at each plot in duplicates with $40 \times 40 \mathrm{~cm}$ quadrats established at opposite sides of the transect. The litter from each quadrat was rinsed, air-dried for $48 \mathrm{~h}$, and weighed. A representative subsample of $\sim 10 \mathrm{~g}$ was taken to the laboratory, where it was dried at $60^{\circ} \mathrm{C}$ and reweighed. The amount of biomass was estimated as dry weight per area (ha). Forest litter biomass was converted to $\mathrm{C}$ and $\mathrm{N}$ stock on the basis of its $\mathrm{C}$ and $\mathrm{N}$ content, which was measured with an elemental analyser coupled to an isotopic ratio mass spectrometer (EA-IRMS, Sercon System, Griffith University).

\subsubsection{Downed wood}

Downed wood was sampled at each plot with the planar intersect technique (Brown et al. 1982) adapted for mangroves by Donato \& Kauffman (2012). The wood pieces were sorted into three categories: small ( $<2 \mathrm{~cm}$ width), large-sound, and large-rotten. Wood density was measured from 50 pieces of wood collected across sampling sites as dry weight divided by volume measured as water displacement. The $\mathrm{C}$ content in the downed wood was estimated by multiplying the mean wood biomass by a factor of 0.5 (Kauffman et al. 1995) and by a factor of 0.005 for N (Gong \& Ong, 1990; Romero et al., 2005). In the 5 and 15-year old plots, recent downed wood was separated from downed wood from the previous harvest, which was clearly identified because widths of older downed wood were larger than those of standing trees. 
In each plot, a soil core of one meter length was taken with a stainless steel open auger of 6.4 $\mathrm{cm}$ diameter $\left(1,609 \mathrm{~cm}^{3}\right)$ attached to a cross handle. Soil samples of known volumes were collected at each plot $(n=5$ per site) from at least four depths $(0-15,15-30,30-50,>50 \mathrm{~cm})$. To assess small scale variability with depth, we collected an extra core at each site and divided it to six depths $(0-10,10-20,20-30,30-40,40-50,>50 \mathrm{~cm})$. Interstitial salinity was measured from the water within the hole from where the core was retrieved. Salinity was measured with a hand-held refractometer (ATAGO Master-S/Milla). Soil depth was estimated by inserting a 2-meter aluminium rod of $1 \mathrm{~cm}$ in diameter in the soil and measuring the depth of the horizon between organic matter and parental bedrock material. The soil samples were air-dried in the field, and then oven-dried in the laboratory at $60^{\circ} \mathrm{C}$. Bulk density was calculated by dividing dry weight by volume of the sample. Roots were not removed from the soil samples, thus the soil includes live roots recently produced and dead roots preserved in the soil, which usually comprise most of the soil OC in mangrove forests (Adame et al. 2017). To reduce costs of analysing a large number of soil samples $(n=163)$, two thirds of the samples ( $n=103$; plots 1,3 and 5 at each site) were analysed for $\% \mathrm{C}$ and $\%$ N (EA-IRMS, Sercon System, Griffith University). Additionally, all the samples were analysed for organic matter (OM) using the loss of ignition method (Heiri et al., 2001). There is a strong correlation between organic carbon (OC), OM and bulk density (e.g. Adame et al. 2016, Fig 1S) from which we calculated the rest of the OC values. All soil samples were corrected for inorganic C (Heiri et al., 2001), although in all samples it was low $(<10 \%)$. 
183 To estimate ecosystem C stocks we compiled published data on tree biomass within the MMFR (Table 1S). Mean tree biomass with forest age is quite consistent due the design of the planting and managing of the forest. For example, forest yields between 1980-1989 were 177 tonnes $\mathrm{ha}^{-1}$, between 1990-1999 were 175 tonnes $^{-1} \mathrm{a}^{-1}$, and between 2000 and 2009 were 179 tonnes ha $^{-1}$. Tree biomass from plots of different ages was obtained from published values of biomass (which were estimated from diameter at breast height and allometric formulas) by Ong et al. (1984), Gong et al. (1984), Putz and Chan (1896), Azahar et al. (2005), Alongi et al. (2004), Goessens et al. (2014), Hazady et al. (2014) (Table 1S). Tree C stocks were obtained by multiplying tree biomass by a factor of 0.48 (Kauffman \& Donato, 2012). Tree $\mathrm{N}$ stock was obtained by multiplying biomass content by 0.005 (Gong \& Ong, 1990). Tree $\mathrm{C}$ and $\mathrm{N}$ stock were added to forest litter, downed wood, and soil to estimate changes in ecosystem stocks through time.

\subsubsection{Origin, stability, and decomposition of soil C}

We analysed 103 samples for $\delta^{13} \mathrm{C}$ and $\delta^{15} \mathrm{~N}$, which are ratios of light and heavy isotopes, which are useful proxies of $\mathrm{C}$ and $\mathrm{N}$ origin and soil decomposition (Adame \& Fry, 2016). The most likely sources of $\mathrm{C}$ and $\mathrm{N}$ from mangrove soils are mangrove material (roots, wood and litter) and phytoplankton transported during tidal inundation (Adame \& Fry, 2016). We analysed 14 samples of mangrove litter fall from each site. Phytoplankton were sampled along the Sepetang River at 11 locations by filtering water through a $20-\mu \mathrm{m}$-mesh plankton net. In the laboratory, phytoplankton was retained by filtration onto pre-combusted Whatman GF/C glass fibre-filters. 
U.S.A). The analytical standard deviation of the standards were $<0.1 \%$ for $\delta^{13} \mathrm{C}$ and $<0.2$

$\%$ for $\delta^{15} \mathrm{~N}$. The stability of the soil $\mathrm{C}$ and $\mathrm{N}$ was determined from the variation of the $\delta^{13} \mathrm{C}$ and $\delta^{15} \mathrm{~N}$ values within depth of mangrove stands of different ages. We expected that if $\mathrm{C}$ and $\mathrm{N}$ amounts were stable, their isotopic values will remain constant with depth; if the soil was perturbed after tree harvest, $\delta^{13} \mathrm{C}$ values should become enriched as a result of increased decomposition (Nadelhoffer \& Fry, 1988; Adame \& Fry, 2016).

\subsection{Statistical analyses}

Linear regressions were conducted to assess the relation between $\% \mathrm{C}$ and $\% \mathrm{~N}$ (dependent variables) and bulk density and \%OC (explanatory variables) using linear regressions (SPSS v24, IBM, New York, USA). To obtain rates of $\mathrm{C}$ and $\mathrm{N}$ accumulation, we modelled the stock of $\mathrm{C}$ and $\mathrm{N}$ as an additive function of time using generalised additive models (Wood 2011). We used a Gaussian distribution and thin-plate regression spines for the two predictor variables. We set the $k$ parameter (upper limit on effective degrees of freedom) to 5 for all components. We chose this value of $k$ because it was sufficient to all non-linearities in the splines and this value also ensured the model assumptions were met (Wood 2006). Predicted $\mathrm{C}$ and $\mathrm{N}$ stock values were given as means for the average plot, with standard errors. We also used the generalised additive models to estimate the change in the tree and soil $\mathrm{C}$ stocks over time from values obtained from the literature for the MMFR. C and N sequestration rates were estimated from the changes in time of the mean predicted values. 
To compare isotope values among forests of different ages and among soil depths, we

231

232

233

234

235

236

237

238

239

240

241

242

243

244

245

246

247

248

used depth and age as fixed factors and plot as the random factor of the ANOVA model.

Normality was assessed with probability plots and the Shapiro-Wilk test. When the variable was not normally distributed (e.g. $\left.\delta^{15} \mathrm{~N}\right)$, it was transformed $\left(\log _{10} \mathrm{x}\right)$. When transformations were not enough to achieve normality (e.g. N:C), the samples were analysed with the nonparametric Kruskal Wallis test. Statistical tests were performed with R and SPSS Statistics (v24, IBM, New York, USA). Values reported are means and standard errors, unless specified otherwise.

\section{Results}

\subsection{Forest litter}

Forest litter biomass ranged between $1.7 \pm 0.5 \mathrm{Mg} \mathrm{ha}^{-1}$ in the 5 year-old forest to $3.7 \pm 0.7$ $\mathrm{Mg} \mathrm{ha}^{-1}$ in the 30 year-old forest. The litter accumulated in the floor corresponds to a minimum of $0.78 \pm 0.2 \mathrm{MgC} \mathrm{ha}^{-1}$ and $0.02 \pm 0.00 \mathrm{Mg} \mathrm{N}^{-1}$ and a maximum of $1.7 \pm 0.3$ $\mathrm{Mg} \mathrm{C} \mathrm{ha}^{-1}$ and $0.03 \pm 0.01 \mathrm{Mg} \mathrm{N}^{-1}$ (Table 2). The $\mathrm{C}$ accumulation of forest litter was highest during the first eight years with $0.01 \pm 0.00 \mathrm{Mg} \mathrm{Cha}^{-1} \mathrm{yr}^{-1}$, then decreased to values $\leq$ $0.005 \mathrm{Mg} \mathrm{C} \mathrm{ha}^{-1} \mathrm{yr}^{-1}$ after 42 years (Fig. 2a). Similarly, N accumulated at a rate of $0.004 \pm$ $0.000 \mathrm{Mg} \mathrm{N} \mathrm{ha}^{-1} \mathrm{yr}^{-1}$ in the first 15 years, and at rates $\leq 0.001 \pm 0.000 \mathrm{Mg} \mathrm{N} \mathrm{ha}^{-1} \mathrm{yr}^{-1}$ from 34 years onwards (Fig. 2d). At seven years, the amount of forest litter was $50 \%$ of the original stock in the reference forest. The clear- cut site had no forest litter, thus, one year after tree harvest, $0.93 \pm 0.15 \mathrm{Mg} \mathrm{C}^{1}{ }^{1}$ and $0.02 \pm 0.00 \mathrm{Mg} \mathrm{N} \mathrm{ha}^{-1}$ of forest litter was lost from the forest, either by decomposition, consumption or tidal exchange. 


\subsection{Downed wood}

254 The density of small pieces of downed wood averaged $1.09 \pm 0.1 \mathrm{~g} \mathrm{~cm}^{-3}$, the density for 255 large-sound wood averaged $1.24 \pm 0.1 \mathrm{~g} \mathrm{~cm}^{-3}$, and for large-rotten wood averaged $0.71 \pm 0.1$ $\mathrm{g} \mathrm{cm}^{-3}$. Downed wood stocks ranged from 10.4 to $62.7 \mathrm{Mg} \mathrm{C}$ ha $^{-1}$ and from 0.11 to $0.63 \mathrm{Mg} \mathrm{N}$ $\mathrm{ha}^{-1}$ for the 5 year old and reference forest, respectively (Table 2). Downed wood accumulation increased linearly with age with a constant mean rate of $0.80 \mathrm{Mg} \mathrm{Cha}^{-1} \mathrm{yr}^{-1}$ and $0.07 \mathrm{Mg} \mathrm{N} \mathrm{ha}^{-1} \mathrm{yr}^{-1}$ (Figure 2b, e). At 35 years, the amount of downed wood was $50 \%$ of the original stock (Figure $2 \mathrm{~b}, \mathrm{e}$ ). The clear-cut and the 5 year-old mangrove had 76 and $58 \mathrm{Mg} \mathrm{ha}$

${ }^{1}$ of downed wood biomass from the previous harvest, respectively, so five years after tree harvest most of the downed wood was still decomposing in the mangrove floor. At 15 years, the downed wood from previous harvest had mostly disappeared.

\subsection{Soil}

Mangrove soil was deeper than $2.5 \mathrm{~m}$ at all sampled sites. Soil $\% \mathrm{OC}$ and $\% \mathrm{~N}$ increased with forest age (Table 3). Lowest values were measured in the surface of the clear-cut stand with $6.3 \pm 0.5 \% \mathrm{OC}$ and $0.35 \pm 0.02 \% \mathrm{~N}$; highest $\% \mathrm{OC}$ values were measured in deep soils $(50-$ $100 \mathrm{~cm}$ ) of the reference forest with $19.4 \pm 0.9 \%$ and highest $\% \mathrm{~N}$ was measured in the surface of the 30 -year old forest with $0.79 \pm 0.14 \%$. Bulk density ranged between $0.26 \pm 0.02$ $\mathrm{g} \mathrm{cm}^{-3}$ in the 30-year old forest and $0.43 \pm 0.03 \mathrm{~g} \mathrm{~cm}^{-3}$ in the clear-cut forest (Table 3). In all

272 samples, the inorganic $\mathrm{C}$ fraction was $<10 \%$ of the total $\mathrm{C}$, but usually $<5 \%$. Soil bulk density was significantly correlated with $\% \mathrm{OC}$ and $\% \mathrm{~N}\left(\mathrm{y}=-43.3 \mathrm{x}+29.6, R^{2}=0.62, p\right.$ $<0.001$; and $\mathrm{y}=-1.15 \mathrm{x}+0.94, R^{2}=0.53, p<0.01$, respectively, Fig. S1), so that high \%OC and $\% \mathrm{~N}$ was measured in soil with low density. Soil $\% \mathrm{OC}$ and $\% \mathrm{~N}$ were also correlated with 
soil \%OM, but only when the clear-cut site was excluded $\left(y=0.37 x-0.063, R^{2}=0.61\right.$, $\mathrm{p}<0.001 ;$ and $\mathrm{y}=0.013 \mathrm{x}+0.063 ; \mathrm{R}^{2}=0.78 ; \mathrm{p}<0.001$, respectively, Figure $\left.1 \mathrm{~S}\right)$.

$$
\begin{aligned}
& \text { The clear-cut mangrove soils had } 29.3 \% \text { less OC and } 24.2 \% \text { less } \mathrm{N} \text { than the reference } \\
& \text { mangrove forest, suggesting that after clearing a forest, about a third of soil OC and a fourth } \\
& \text { of soil } \mathrm{N} \text { is lost. Additionally, the clear-cut forest had } 18.7 \% \text { less } \mathrm{C} \text { and } 14.4 \% \text { less } \mathrm{N} \text { than } \\
& \text { the forest at } 30 \text { years, suggesting that clearing a managed forest causes the loss of about a } \\
& \text { sixth of the soil C and } \mathrm{N} \text {. Soil OC and } \mathrm{N} \text { loss in the clear-cut site was observed throughout } \\
& \text { the sediment column to depths of up to } 1 \mathrm{~m} \text { (Table } 3 \text { ). }
\end{aligned}
$$

5

Soil OC and $\mathrm{N}$ stocks increased with forest age from $385.2 \pm 72.6 \mathrm{MgC} \mathrm{ha}^{-1}$ and 15.7 $\pm 1.80 \mathrm{MgN} \mathrm{ha}^{-1}$ in the clear-cut site to $545.0 \pm 113.4 \mathrm{MgC} \mathrm{ha}^{-1}$ and $20.73 \pm 1.77 \mathrm{MgN} \mathrm{ha}^{-1}$ in the reference forest (Fig 2c, e). The highest soil OC stock was measured in the reference forest $\left(F_{5,25}=5.86, p=0.001\right)$. Soil OC accumulation was $5.7 \pm 0.2 \mathrm{MgC} \mathrm{ha}^{-1} \mathrm{yr}^{-1}$ in the first ten years after replantation, which decreased to $\leq 5 \mathrm{Mg} \mathrm{C} \mathrm{ha}^{-1} \mathrm{yr}^{-1}$ until 40 years. After 40 years, accumulation rates were variable between 0.2 to $7.6 \mathrm{Mg} \mathrm{C} \mathrm{ha}^{-1} \mathrm{yr}^{-1}$, probably due to low $\mathrm{C}$ stocks in the 40 years forest (Fig 2c). When analysing our soil C stocks with those estimated from published data (Alongi, 2004) we found accumulation rates of $2.9 \pm 0.0 \mathrm{Mg} \mathrm{C}$ $\mathrm{ha}^{-1} \mathrm{yr}^{-1}$ in the first ten years decreasing to rates $\leq 1.2 \mathrm{Mg} \mathrm{Cha}^{-1} \mathrm{yr}^{-1}$ after 50 years (Fig. 3b). Soil $\mathrm{N}$ accumulation followed a linear trajectory, with a constant accumulation rate of $0.07 \mathrm{Mg} \mathrm{N} \mathrm{ha}^{-1} \mathrm{yr}^{-1}$ (Fig. 2f). It took about 50 years for soil OC and about 35 years for soil $\mathrm{N}$ to recover half of the losses after clearing (Fig 2c,d, 3b) 


\subsection{Ecosystem C and N stocks}

The trajectory of tree $\mathrm{C}$ stocks was analysed from published data (Table 1S). Tree C accumulation was $4.4 \pm 0.0 \mathrm{MgC} \mathrm{ha}^{-1} \mathrm{yr}^{-1}$ in the first 12 years, decreasing to values $\leq 1 \mathrm{Mg}$ $\mathrm{C} \mathrm{ha}^{-1} \mathrm{yr}^{-1}$ after 62 years. It took 24 years, for the forest to reach half of the reference tree $\mathrm{C}$ stock (Fig. 3a).

Total C and N stocks (including forest litter, downed wood, soil and trees) generally increased with forest age from $385.2 \pm 72.6 \mathrm{Mg} \mathrm{C} \mathrm{ha}^{-1}$ and $15.7 \pm 1.8 \mathrm{Mg} \mathrm{N}^{-1}$ in the clearcut forest, to maximum values of $895.8 \pm 113.9 \mathrm{Mg} \mathrm{C} \mathrm{ha}^{-1}$ and $24.6 \pm 1.8 \mathrm{Mg} \mathrm{N}^{-1}$ in the reference forest. The clear-cut forest had $57 \%$ of the $\mathrm{C}$ and $37 \%$ of the $\mathrm{N}$ of the reference forest, suggesting that tree clear-cutting causes the loss of more than half of the total mangrove ecosystem $\mathrm{C}$, and more than a third of the ecosystem $\mathrm{N}$ within a year. In the first 10 years, rates of $\mathrm{C}$ accumulation were $9.5 \mathrm{Mg} \mathrm{C} \mathrm{ha}^{-1} \mathrm{yr}^{-1}$, after which rates decreased to 2.8 $\mathrm{Mg} \mathrm{Cha}^{-1} \mathrm{yr}^{-1}$.

\subsection{Pathways of C accumulation and loss}

The mangrove soil had a mean $\delta^{13} \mathrm{C}$ value of $-28.6 \pm 0.04 \%$ (range $=-27.6$ to $-29.9 \%$ ) and $\delta^{15} \mathrm{~N}$ value of $3.1 \pm 0.1 \%$ ( 0.9 to $8.8 \%$ ). The $\delta^{13} \mathrm{C}$ values in the soil were close to those of mangrove litter, which were $-29.4 \pm 0.1 \%$, consistent with a mangrove origin for the soil OC (Fig. 4). For $\delta^{15} \mathrm{~N}$, relatively large differences between sites were evident for soils (1.3 to 6.2 $\%$ ), but they were all well within the values of mangrove litter. Isotope values from phytoplankton were variable, but in general higher in $\delta{ }^{13} \mathrm{C}$ compared to the mangrove soil. 
321 Phytoplankton $\delta{ }^{15} \mathrm{~N}$ (mean= $-25.5 \pm 0.8 \%, 30.4$ to -21.1$)$ were similar to those of mangrove litter (mean $=6.1 \pm 0.7 \%$; 1.1 to $9.2 \%$ ). significantly higher mean $\delta{ }^{13} \mathrm{C}$ value $(-28.09 \pm 0.02 \%)$ than the observed at rest of the sites $\left(F_{5,8.9}=20.48, p<0.001\right.$; Fig. $\left.4 \mathrm{a}\right)$. For $\delta^{15} \mathrm{~N}$, the clear-cut mangrove soil, and those of the 5year old and 40-year old forests had significantly higher values ( $>3 \%$ ) compared to soils of the 16-year forest, 30-year forest and the reference forest $\left(F_{8,9.5}=6.36, p=0.007\right.$; Fig. 4$)$. The $\mathrm{N}: \mathrm{C}$ values were not significantly different among sites $(p=0.065)$ or depths $(p=0.093)$, although the clear cut site and the 40-year old site had notably higher $\mathrm{N}: \mathrm{C}$ in the first $50 \mathrm{~cm}$ of sediment of soil compared to the rest of the sites (Fig. 4c). Among soil depths, $\delta{ }^{13} \mathrm{C}$ was about $0.6 \%$ enriched in the deep sediment compared to the surface $\left(F_{8,40.3}=3.51, p=\right.$ $0.005)$. Finally, $\delta^{15} \mathrm{~N}$ values were not significantly different within depths $\left(F_{8,24.6}=1.91, p=\right.$ 0.104; Fig. 4b). The clear cut site was notably different from the rest of the sites, with higher $\delta^{13} \mathrm{C}, \delta^{15} \mathrm{~N}$ and $\mathrm{N}: \mathrm{C}$ values. In general, mangrove soils were depleted in $\delta^{13} \mathrm{C}, \delta^{15} \mathrm{~N}$ and decreased in $\mathrm{N}: \mathrm{C}$ with age, consistent with decreased decomposition (Table 2S).

\section{Discussion}

One year after tree harvest, mangrove ecosystem $\mathrm{C}$ and $\mathrm{N}$ stocks were halved. In the 340 first ten years, the forest recovered quickly with rates of $\mathrm{C}$ accumulation of $9.5 \mathrm{Mg} \mathrm{C} \mathrm{ha}^{-1} \mathrm{yr}^{-}$

341 , primarily as a result of rapid tree and root growth in this humid-warm and nutrient-rich 342 environment. After ten years, the rate of accumulation decreased to $2.8 \mathrm{Mg} \mathrm{C} \mathrm{ha}^{-1} \mathrm{yr}^{-1}$. Forty 
years after replanting, mangroves were still a $26 \%$ lower in $\mathrm{C}$ and $15 \%$ lower in $\mathrm{N}$ compared to the reference forest.

After tree harvest, soil $\delta^{13} \mathrm{C}$ values significantly increased throughout the sediment column, an effect likely due to decomposition (Nadelhoffer \& Fry, 1988; Adame \& Fry, 2016). In the surface, increased $\delta^{13} \mathrm{C}$ values could also partly reflect increased benthic microalgal photosynthesis in the newly open forests (Lovelock, 2008). Mangroves in MMFR have respiration rates of $0.5-1.8 \mathrm{MgC} \mathrm{ha}^{-1} \mathrm{yr}^{-1}$, and oxidation rates of 3.4-5.2 $\mathrm{Mg} \mathrm{C} \mathrm{ha}^{-1} \mathrm{yr}^{-1}$

351 (Alongi et al., 2004). Our measured rate of loss of soil $\mathrm{C}$ after perturbation of $3.1 \mathrm{Mg} \mathrm{C}^{-1}$ $\mathrm{yr}^{-1}$ is well within these expected ranges.

Nitrogen dynamics followed a similar pattern to $\mathrm{C}$ variations. The $\mathrm{N}$ budget in mangrove forests is primarily the sum of outputs (denitrification-nitrification, plant uptake) and inputs ( $\mathrm{N}$ fixation and sediment burial). MMFR has denitrification rates of $0.04-1.1 \mathrm{Mg}$ $\mathrm{N} \mathrm{ha}^{-1} \mathrm{yr}^{-1}$, plant uptake of $0.8-2.3 \mathrm{Mg} \mathrm{N} \mathrm{ha}^{-1} \mathrm{yr}^{-1}$, sediment burial of $0.3-0.4 \mathrm{Mg} \mathrm{N}^{-1} \mathrm{yr}^{-1}$ and low $\mathrm{N}$ fixation rates, which ranged from undetectable to $0.3 \mathrm{Mg} \mathrm{N} \mathrm{ha}^{-1} \mathrm{yr}^{-1}$, (Alongi et al., 2004). In general, mangrove forests of MMFR are considered sinks of 0.8 to $3.5 \mathrm{Mg} \mathrm{N}$ ha$^{-}$ ${ }^{1} \mathrm{yr}^{-1}$ (Alongi et al., 2004). Our estimated net ecosystem $\mathrm{N}$ uptake rate after restoration is between 0.1 and $0.6 \mathrm{Mg} \mathrm{N} \mathrm{ha}^{-1} \mathrm{yr}^{-1}$, values within the lower end of measurements by Alongi et al. (2004). 
of organic matter, increased respiration, decreased denitrification, and decreased sediment burial, all of which results in C and N loss (Rivera-Monroy \& Twilley, 1996; Alongi et al., 1998; Sidik \& Lovelock, 2013). After replantation, soil $\delta^{13} \mathrm{C}$ values stabilized around -29\%o, a value similar to mangrove litter. It is likely that at after replantation, a gradual shift from aerobic to anaerobic soil conditions occurs, with anaerobic reactions such as sulphate reduction dominating (Alongi et al., 1998) and limiting C loss. Regrowth of roots following tree replantation may account for most of the early $(<5$ years) recovery of soil C stocks (Adame and Fry 2016, Adame et al. 2017).

In the first five years, soil $\mathrm{C}$ accumulation rates were between 2.9 and $6.1 \mathrm{Mg} \mathrm{C} \mathrm{ha}^{-1}$ $\mathrm{yr}^{-1}$, which were twice as large as those in mature forests (> 50 years) that were $\leq 1.2 \mathrm{Mg} \mathrm{C}$ $\mathrm{ha}^{-1} \mathrm{yr}^{-1}$. Our estimates of $\mathrm{C}$ accumulation in mature forests were similar to previous assessments of soil OC accumulation of 2-2.5 $\mathrm{Mg} \mathrm{C} \mathrm{ha}^{-1} \mathrm{yr}^{-1}$ in planted forests in MMFR estimated with ${ }^{210} \mathrm{~Pb}$ (Alongi et al., 2004), 0.7-4.9 $\mathrm{MgC} \mathrm{ha}^{-1} \mathrm{yr}^{-1}$ in mangrove forests in French Guiana (Marchand, 2017) and 0.4-1.8 $\mathrm{MgC} \mathrm{ha}^{-1} \mathrm{yr}^{-1}$ in mangroves in Mexico (Adame et al., 2015a). Mangrove OC and $\mathrm{N}$ accumulation followed a logarithmic trajectory for soil, trees and litter, with highest sequestration rates in the early years. Similarly, the increase in the soil layer resulting from mangrove progression followed a logarithmic trajectory in mature forests (Alongi, 2011). are likely to contribute to spatial and temporal variations. Mangroves are constantly perturbed 
by natural factors, such as tropical storms which can cause extensive damage to trees (Sherman et al., 2001; Kauffman \& Cole, 2010) and peat collapse (Cahoon et al., 2003). Many mangroves can naturally recover after such perturbations if the conditions are adequate, but some stands may never return to their original condition (Sherman et al., 2000; Baldwin et al., 2001). Additionally, mangrove C accumulation is closely related to sea level (Krauss et al., 2013; Lee et al., 2014), which will increase in the coming decades. Thus, the establishment of a mangrove forests and their rapid rates of $\mathrm{C}$ and $\mathrm{N}$ sequestration do not guarantee continual delivery of this ecosystem service. Based on our results, planted mangroves can recover relatively quickly, but only if the conditions are adequate.

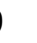

Carbon and $\mathrm{N}$ stocks typically follow a progression with age. However, we found variability within a few sites. The 40-year old forest supports mixed Rhizophora and Brugueira species, and has been conserved for educational purposes and is close to the town of Sepatang. This forest at 40 years had lower C stocks than the managed forests at 30 years. Thus, despite differences in age, the spatial variability within sites, such as nutrient inputs, management, and climate will affect $\mathrm{C}$ and $\mathrm{N}$ sequestration potential for different mangrove forests.

The differences among sites with age in $\mathrm{C}$ and $\mathrm{N}$ content can be translated into delivery of ecosystem services. For example, our reference had twice as much downed wood as the rest of the forests. Downed wood could be an important habitat for fauna in mangrove forests (Allen et al., 2000; Feller \& Chamberlain, 2007). Thus, restoration of mangroves, as with any other ecosystem, might have resulted in a novel type of forest (Hobbs et al., 2009) with lower habitat diversity. 
Our results provide valuable information on the rates of loss and recovery of $\mathrm{C}$ and $\mathrm{N}$

416 after mangrove clearing and replantation in Malaysia. However, the comparison with other

417 mangrove forests needs to be made with caution, because variability within environmental

418 factors and management practices will strongly affect $\mathrm{C}$ and $\mathrm{N}$ sequestration rates.

Mangroves in Asia Pacific are very productive and have the highest soil C stocks on Earth

420 (Atwood et al., 2017). In MMFR conditions for mangroves are ideal, with warm

temperatures, high rainfall and high nutrients; factors contributing to high forest productivity

(Reef et al., 2010). Additionally, replantation of the mangroves in the MMFR occurs in soil lower for other mangrove forests in less productive locations. In some cases, $\mathrm{C}$ and $\mathrm{N}$ gains could be close to zero if the soil has been strongly perturbed and the conditions for plant growth are inadequate (Kodikara et al., 2017). Nevertheless, in this study we describe the best account to date for long-term $\mathrm{C}$ and $\mathrm{N}$ loss and sequestration rates in mangrove forests.

\subsection{Implications for the Matang Mangrove Forest Reserve} charcoal wood supply. However, with concerns of decreased tree productivity and the decline on the price of charcoal, C markets could be an attractive option (Ullman et al., 2013, Ammar et al., 2014). 
437 clearing. After replanting, the forest recovers relatively quickly in the first ten years, although

438 there is likely to be a small loss of carbon every clearing-planting cycle which results in lower $\mathrm{C}$ stocks in the managed versus the reference forest (Fig. 5). If instead of clearing and planting, the forest is protected and left to recover for 70 years, it will sequester 1735 $\mathrm{MgCO}_{2 \mathrm{eq}} \mathrm{ha}^{-1}$. The protection of the mangroves compared to the business-as-usual scenario in which the forest is continuously clear cut and planted, will provide reduced carbon emissions of $572 \mathrm{MgCO}_{2 \text { eq }} \mathrm{ha}^{-1}$ (Fig. 5). The reduced carbon emissions could be worth \$USD 4,574 based on the Chinese market in 2017 in which $\mathrm{C}$ is valuated at $\$ 8$ USD per Mg. If 1,000 ha of mangroves were changed protected, the revenue is \$USD 4.6 million in 40 years, or \$USD 114,348 per year. In addition to the avoided emissions, the conservation of mangrove forests will provide habitat for birds, improved fisheries, and costal protection, which could also be considered in the future for payments for ecosystem services (PES, Locatelli et al. 2014).

\footnotetext{
The sustainable management of the MMFR has allowed for productive mangroves to be maintained in this region for over a century. The rates of loss and gain of $\mathrm{C}$ and $\mathrm{N}$ estimated in this study could facilitate the inclusion of mangroves in emerging $\mathrm{C}$ and $\mathrm{N}$ markets. These results could also provide an incentive to the protection, restoration, and sustainable management of mangrove forests in the Indo-Pacific region and in similar mangrove forests throughout the world.
}

\section{Acknowledgements}



supported by RU026-2015, an IRU-MRUN Global Collaborative Research Programme grant

461 awarded to SYL and VCC. We thank the Forestry Department of the Perak State for

462 permission to conduct field work in MMFR. We also thank Jamizan A. Rahman and Jennice

463 Yap for assistance during fieldwork. This work was supported by funding from the

464 Queensland Government through the Advance Queensland Fellowship, and the National

465 Environmental Research Program (Project 3.3.2) granted to MF Adame. 


\section{References}

468 Adame, M. F., Fry, B., 2016. Source and stability of soil carbon in mangrove and freshwater

469 wetlands of the Mexican Pacific coast. Wetl. Ecol. Manag. 24, 1-9, doi:10.1007/s11273-015$470 \quad 9475-6,2016$.

471 Adame, M.F., Hermoso, V., Perhans, K., Lovelock, C.E., Herrera-Silveira, J.A., 2015a.

472 Selecting cost-effective areas for restoration of ecosystem services. Cons. Biol. 29, 493-502

473 Adame, M. F., Santini, N. S., Tovilla, C., Vázquez-Lule, A., Castro, L., Guevara, M., 2015 b.

474 Carbon stocks and soil sequestration rates of tropical riverine wetlands, Biogeosciences. 12, 475 3805-3818, doi:10.5194/bg-12-3805-2015.

476 Adame, M. F., Cherian, S., Reef, R., Stewart-Koster, B., 2017. Mangrove root biomass and

477 the uncertainty of belowground carbon estimations. For. Ecol. Manage., 403, 52-60,

$478 \quad$ 52doi:10.1016/j.foreco.2017.08.016, 2017.

479 Allen, J., Ewel, K., Keeland, B., Tara, T., Smith III, T.J., 2000. Downed wood in Micronesian 480 mangrove forests. Wetlands. 20, 169-176.

481 Alongi, D., Sasekumar, A., Tirendi, F. and Dixon, P., 1998. The influence of stand age on 482 benthic decomposition and recycling of organic matter in managed mangrove forests of Malaysia. J. Exp. Mar. Bio. Ecol. 225, 197-218.

484 Alongi, D., Sasekumar, A., Chong, V., Pfitzner, J., Trott, L., Tirendi, F., Dixon, P., Brunskill, 485 G., 2004. Sediment accumulation and organic material flux in a managed mangrove 486 ecosystem: estimates of land-ocean-atmosphere exchange in peninsular Malaysia. Mar.

487 Geol., 208, 383-402. 
488

489

490

491

492

493

494

495

496

497

498

499

500

501

502

503

504

505

506

507

508

509

Alongi, D., M., 2011. Carbon payments for mangrove conservation: ecosystem constraints and uncertainties of sequestration potential. Environ. Sci. Policy. 14, 462-470, doi:10.1016/j.envsci.2011.02.004.

Alongi, D. M., 2012. Carbon sequestration in mangrove forests, Carbon Manag. 3, 313-322, doi:10.4155/cmt.12.20.

Ammar, A., Dargusch, P., Shamsudin, I., 2014. Can the Matang mangrove forest reserve provide perfect teething ground for a blue carbon based REDD+ project? J. Trop. For. Sci. 26, 371-381.

Atwood, T. B., Connolly, R. M., Almahasheer, H., Carnell, P. E., Duarte, C. M., Ewers Lewis, C. J., Irigoien, X., Kelleway, J. J., Lavery, P. S., Macreadie, P. I., Serrano, O., Sanders, C. J., Santos, I., Steven, A. D. L., Lovelock, C. E., 2017. Global patterns in mangrove soil carbon stocks and losses. Nat. Clim. Change. 7, 523-528, doi:10.1038/nclimate3326.

Azani, M., Arifin, A., Zaki, M., 2005. Soil properties at five different selected sites in Matang mangrove forest reserve, in: Shaharuddin, M., Azahar, M., Razani, U., Kamurazaman, A., Lim, K., Suhaili, R., Jalil, M., Latiff, A. (Eds.), Sustainable Management of Matang Mangroves: 100 years and beyond, Forestry Department, Kuala Lumpur, Malaysia., pp. 204210.

Baldwin, A., Egnotovich, M., Ford, M., Platt, W., 2001. Regeneration in fringe mangrove forests damaged by Hurricane Andrew. Plant Ecol. 157, 151-164.

Brown, J.K., Oberheu, R.D., Johnston, C.M., 1982. Handbook for inventorying surface fuels and biomass in the interior West. US Department for Agriculture-US Forest Service, 48 pp. 
513 Feller, I., Chamberlain, A., 2007. Herbivore responses to nutrient enrichment and landscape 514 heterogeneity in a mangrove ecosystem, Oecologia, 153(3), 607-616, 2007.

515 Goessens, A., Satyanarayana, B., Van Der Stocken, T., Zuniga, M. Q., Mohd-Lokman, H., 516 Sulong, I., Dahdouh-Guebas, F., 2014. Is Matang Mangrove Forest in Malaysia sustainably 517 rejuvenating after more than a century of conservation and harvesting management? PLoS 518 One, 9, e105069, doi:10.1371/journal.pone.0105069.

519 Gong, W.-K., Ong, J.-E., 1990. Plant biomass and nutrient flux in a managed mangrove 520 forest in Malaysia. Estuar. Coast. Shelf Sci., 31, 519-530.

521 Hamid, H. A., Nuruddin, A. A., Samdin, Z., Tuan Marina, T. I., Mohammad, L. S., 2015.

522 Quantification and economic valuation of carbon stock in the Matang Mangrove Forest 523 Reserve in Perak., Proc. 17th, A century of forest management: Lessons learnt and the way 524 forward, Sabah, Malaysia, 11th -12th November, 2014, 321-335 [online] Available from: 525 https://www.cabdirect.org/cabdirect/abstract/20173097338, 2015.

526 Heiri, O., Lotter, A. F., Lemcke, G., 2001. Loss on ignition as a method for estimating 527 organic and carbonate content in sediments: reproducibility and comparability of results. J. 528 Paleolimnol. 25, 101-110.

529 Hobbs, R., Higgs, E., Harris, J., 2009. Novel ecosystems: implications for conservation and 530 restoration. Trends Ecol. Evol. 24, 599-605. 
531 Kairo, J., Dahdouh-Guebas, F., Bosire, J., Koedam, N., 2001. Restoration and management of 532 mangrove systems- a lesson for and from the East African region. South African J. Bot., 67, $533 \quad 383-389$.

534 Katsuhisa, T., Choo, P-S., 200. Influence of nutrient outwelling from the mangrove swamp 535 on the distribution of phytoplankton in the Matang Mangrove Estuary, Malaysia, J. Oceanogr. $53656,69-78$.

537 Kauffman, J. B., Donato, D. C. 2012. Protocols for the measurement, monitoring and 538 reporting of structure, biomass and carbon stocks in mangrove forests. Working paper 86, 539 Bogor, Indonesia.

540 Kauffman, J. B., Cummings, D. L., Ward, D. E., Babbitt, R., 1995. Fire in the Brazilian 541 Amazon: biomass, nutrient pools, and losses in slashed primary forests. Oecologia. 104, 397542408.

543 Koch, E.W., Barbier, E.B., Silliman, B.R., Reed, D J., Perillo, G.M.E., Hacker, S.D., Granek, 544 E.F., Primavera, J.H., Muthiga, N., Polasky, S., Halpern, B.S., Kennedy, C.J., Kappel, C.V, 545 Wolanski, E., 2009. Non-linearity in ecosystem services: temporal and spatial variability in 546 coastal protection. Front. Ecol. Environ. 7, 29-37.

547 Kodikara, K.A.S., Mukherjee, N., Jayatissa, L. P., Dahdouh-Guebas, F., Koedam, N., 2017. 548 Have mangrove restoration projects worked? An in-depth study in Sri Lanka. Restor. Ecol. $549 \quad 25,705-716$, doi:10.1111/rec.12492, 2017.

550 Krauss, K., McKee, K., Lovelock, C.E., Cahoon, D., Saintilan, N., Reef, R. and Chen, L., 551 2013. How mangrove forests adjust to rising sea level. New Phytol. 202, 19-34. 
552

553

554

555

556

557

558

559

560

561

562

563

564

565

566

567

568

569

570

571

572

Lee, S. Y., 2016. From blue to black: Anthropogenic forcing of carbon and nitrogen influx to mangrove-lined estuaries in the South China Sea. Mar. Pollut. Bull. 109, 682-690, doi:10.1016/j.marpolbul.2016.01.008.

Lee, S.Y., Primavera, J.H., Dahdouh-Guebas, F., Mckee, K., Bosire, J.O., Cannicci, S., Diele, K., Fromard, F., Koedam, N., Marchand, C., Mendelssohn, I., Mukherjee, N. and Record, S., 2014. Ecological role and services of tropical mangrove ecosystems: A reassessment. Glob. Ecol. Biogeogr. 23, 726-743, doi:10.1111/geb.12155.

Lewis, R.R., 2001. Mangrove restoration- costs and measures of successful ecological restoration. In: Proceedings of the Mangrove Valuation workshop, pp. 32134-5430. Beijer International Institute of Ecological Economics, Stockholm, Sweden.

Locatelli, T., Binet, T., Kairo, J.G., King, L., Madden, S., Patenaude, G., Upton, C., Huxham, M. 2014. Turning the tide: how blue carbon and payments for ecosystem services (PES) might help save mangrove forests. Ambio. 43, 981-995. doi:10.1007/s13280-014-0530-y.

Lovelock, C.E. 2008. Soil respiration and belowground carbon allocation in mangrove forests. Ecosystems. 11, 342-354, doi:10.1007/s10021-008-9125-4.

Lovelock, C.E., Ruess, R.W., Feller, I.C. 2011. $\mathrm{CO}_{2}$ efflux from cleared mangrove peat. PLoS One. 6, e21279, doi:10.1371/journal.pone.0021279.

Lugo, A.E., Snedaker, S.C., 1974. The Ecology of Mangroves, Annu. Rev. Ecol. Syst., 5, 3964.

Malaysian Meteorological Department, http://www.met.gov.my/web/metmalaysia/climate/ viewed 28 Sept, 2017 
573 Marchand, C. 2017. Soil carbon stocks and burial rates along a mangrove forest

574 chronosequence, For. Ecol. Manage. 384, 92-99.

575 Mitsch, W.J., Gosselink, J. 2015. Wetlands, 5th ed., Wiley, New Jersey, USA.

576 Murdiyarso, D., Purbopuspito, J., Kauffman, J.B., Warren, M.W., Sasmito, S.D., Donato, D.

577 C., Manuri, S., Krisnawati, H., Taberima, S. and Kurnianto, S. 2015. The potential of

578 Indonesian mangrove forests for global climate change mitigation. Nat. Clim. Chang. 5, 579 1089-1092, doi:10.1038/nclimate2734, 2015.

580 Nadelhoffer, K.J., Fry, B., 1988. Controls on natural Nitrogen-15 and Carbon-13 abundances 581 in forest soil organic matter. Soil Sci. Soc. Am. J. 52, 1633-1640.

582 NHCM, National Hydrography Centre Malaysia. Malaysian Tide Table 2017. Royal 583 Malaysian Navy.

584 Ouyang, X., Guo, F., 2016. Paradigms of mangroves in treatment of anthropogenic 585 wastewater pollution. Sci. Total Environ. 544, 971-979, doi:10.1016/j.scitotenv.2015.12.013, 5862016.

587 Ong, J-E., Gong, W., Wong, C., Dhanarajan, G., 1984. Contribution of aquatic productivity 588 in managed mangrove ecosystem in Malaysia. In: Sopeadmo E., Rao A., MacIntosh D. 589 (Eds.), Proceedings of the Asian symposium on mangrove environment- Research and 590 management, Kuala Lumpur, Malaysia, pp. 209-215.

591 Ramarn, T., Chong, V., Hanamura, Y. 2012., Population structure and reproduction of the 592 mysid shrimp Acanthomysis thailandica (Crustacea: Mysidae) in a tropical mangrove estuary, 593 Zool. Stud. 51, 768-782. 
594

595

596

597

598

599

600

601

602

603

604

605

606

607

608

609

610

611

612

613

614

Reef, R., Feller, I.C. and Lovelock, C.E., 2010. Nutrition of mangroves. Tree Physiol. 30, 1148-1160, doi:10.1093/treephys/tpq048.

Rivera-Monroy, V.H., Twilley, R.R., 1996. The relative role of denitrification and immobilization in the fate of inorganic nitrogen in mangrove sediments (Terminos Lagoon, Mexico). Limnol. Oceanogr. 41, 284-296.

Romero, L., Smith, T., Fourqurean, J., 2005. Changes in mass and nutrient content of wood during decomposition in a south Florida mangrove forest. J. Ecol. 93, 618-631, doi:10.1111/j.1365-2745.2005.00970.x, 2005.

Shaharuddin, M., Azahar, M., Razani, U., Kamurazaman, A., Lim, K., Suhaili, R., Jalil, M. and Latiff, A., Sustainable management of Matang Mangroves: 100 years and beyond, Forestry Department, Kuala Lumpur, Malaysia, 2005.

Sherman, R.E., Fahey, T.J., Battles, J.J., 2000. Small-scale disturbance and regeneration dynamics in a neotropical mangrove forest. J. Ecol. 88, 165-178, doi:10.1046/j.13652745.2000.00439.x.

Sidik, F., Lovelock, C.E. 2013. $\mathrm{CO}_{2}$ efflux from shrimp ponds in Indonesia, PLoS One, 8, 69, doi:10.1371/journal.pone.0066329.

Ullman, R., Bilbao-Bastida, V., Grimsditch, G., 2013. Including Blue Carbon in climate market mechanisms, Ocean Coast. Manag. 2013, 83, 15-18

Walton, M., Le Vay, L., Junemie, H., Binas, J., Primavera, J., 2007. Assessment of the effectiveness of mangrove rehabilitation using exploited and non-exploited indicator species. Biol. Cons. 138, 180-188. 
615 Wood, S.N., 2006. Generalized additive models: An introduction with R. Chapman and 616 Hall/CRC.

617 Wood, S.N., 2011. Fast stable restricted maximum likelihood and marginal likelihood 618 estimation of semiparametric generalized linear models. J. Royal Stat. Soc. 73, 3-36.

619 Zaldívar-Jiménez, M.A., Herrera-Silveira, J.A., Teutli-Hernández, C., Comín, F.A., Andrade, 620 J.L., Molina, C.C., Ceballos, R.P., 2010. Conceptual framework for mangrove restoration in 621 the Yucatan Peninsula. Ecol. Rest.28, 333-342.

622

623 


\section{Figure legends}

625 Fig. 1. Sampling locations in the Matang Mangrove Forest Reserve, Peninsular Malaysia.

626 Sampling sites are indicated by numbers corresponding to years after clear cutting; 1 - clear-

627 cut or one year after tree harvest, 5-year old mangroves, 15-year old mangroves, 30-year old

628 mangroves, 40-year old mangroves, and a 70- year old mangrove, which was considered the 629 reference forest.

630

631

Figure 2. Carbon (C) and nitrogen (N) stocks $\left(\mathrm{Mg} \mathrm{ha}^{-1}\right)$ after mangrove replantation for $(\mathrm{a}, \mathrm{d})$

632 forest litter, (b,e) downed wood, and (c,f) soil in Matang Mangrove Forest Reserve, Peninsular Malaysia. The dotted lines represent standard errors and the shaded area shows the period after which $50 \%$ of the original stock has been recovered.

Figure 3. Carbon (C) stocks $\left(\mathrm{Mg} \mathrm{ha}^{-1}\right)$ after mangrove replantation for (a) trees and (b) soil in Matang Mangrove Forest Reserve. Tree data was estimated from published biomass values from Ong et al. (1984), Gong et al. (1984), Putz and Chan (1896), Azahar et al. (2005), Alongi et al. (2004), Goessens et al. (2014), and Hazady et al. (2014). Soil data from this study and those estimated from C values in Alongi et al. (2004).

642 Figure 4. (a,b) Isotope values $\left(\delta^{13} \mathrm{C}\right.$ and $\delta^{15} \mathrm{~N} ; \%$ o) and (c) $\mathrm{N}: \mathrm{C}$ values of soils in mangrove 643 stands of different ages and depths in Matang Mangrove Forest Reserve, Malaysia. Each 644 value represents the mean \pm standard error of 3 to 5 plots. The shaded area indicates values of 645 mangrove litter (range). 
646 Figure 5. Conceptual diagram of avoided emissions resulting from changes in land use

647 practices from clear cutting-planting mangroves to conservation in Matang Mangrove Forest 648 Reserve, Peninsular Malaysia.

649 
Table 1. Characteristics of mangrove forests in Matang Mangrove Forest Reserve,

652 Malaysia.

\begin{tabular}{|c|c|c|c|}
\hline Location & Stand age & Stand description & $\begin{array}{l}\text { Interstitial salinity } \\
(\mathrm{ppt})\end{array}$ \\
\hline $\begin{array}{c}4^{\circ} 50.714^{\prime} \\
100^{\circ} 35.937^{\prime}\end{array}$ & $\begin{array}{c}0 \\
\text { (“clear-cut”) }\end{array}$ & Harvested & $14.8 \pm 0.6$ \\
\hline $\begin{array}{c}4^{\circ} 48.914, \\
100^{\circ} 37.297\end{array}$ & 5 & Planted & $9.3 \pm 0.3$ \\
\hline $\begin{array}{c}4^{\circ} 49.157^{\prime} \\
100^{\circ} 37.531\end{array}$ & 15 & Planted & $9.7 \pm 0.2$ \\
\hline $\begin{array}{l}4^{\circ} 50.651^{\prime} \\
100^{\circ} 37.287^{\prime}\end{array}$ & 30 & $\begin{array}{l}\text { Planted and } \\
\text { thinned }\end{array}$ & $8.7 \pm 0.6$ \\
\hline $\begin{array}{l}4^{\circ} 50.527^{\prime} \\
100^{\circ} 38.196^{\prime}\end{array}$ & 40 & Reserved & $7.7 \pm 0.8$ \\
\hline $\begin{array}{l}4^{\circ} 50.292^{\prime} \\
100^{\circ} 37.189^{\prime}\end{array}$ & $\begin{array}{c}>70 \\
\text { ("reference") }\end{array}$ & Reserved & $7.7 \pm 0.5$ \\
\hline
\end{tabular}

653

654 
655 Table 2. Carbon $\left(\mathrm{Mg} \mathrm{C} \mathrm{ha}^{-1}\right)$ and nitrogen stock $\left(\mathrm{Mg} \mathrm{N} \mathrm{ha}^{-1}\right)$ in forest litter and downed wood 656 from mangrove forest of different ages in the Matang Mangrove Forest Reserve, Malaysia.

657 The clear-cut site had no forest litter one year after tree harvest. In the 5 and 15 year-old 658 forests, natural downed wood was separated from downed wood of previous harvest (width of 659 wood $>$ DBH of standing trees).

5 years $\quad 15$ years $\quad 30$ years $\quad 40$ years $\quad 70$ years

\section{Forest litter}

$\begin{array}{llllll}\text { C stock } & 0.78 \pm 0.22 & 1.48 \pm 0.29 & 0.93 \pm 0.15 & 1.66 \pm 0.30 & 1.31 \pm 0.25 \\ \text { N stock } & 0.02 \pm 0.00 & 0.03 \pm 0.01 & 0.02 \pm 0.00 & 0.03 \pm 0.01 & 0.03 \pm 0.01\end{array}$

\section{Downed wood}

$\begin{array}{llllll}\text { C stock } & 10.4 \pm 2.3 & 15.3 \pm 2.8 & 35.1 \pm 5.9 & 29.6 \pm 12.1 & 62.7 \pm 10.7 \\ \text { N stock } & 0.11 \pm 0.02 & 0.15 \pm 0.03 & 0.35 \pm 0.06 & 0.30 \pm 0.12 & 0.63 \pm 0.11\end{array}$

660

661 
662 Table 3. Soil organic carbon $(\% \mathrm{OC})$, nitrogen $(\% \mathrm{~N})$, bulk density $\left(\mathrm{g} \mathrm{cm}^{-3}\right)$, organic carbon 663 and nitrogen stocks $\left(\mathrm{Mg} \mathrm{ha}^{-1}\right)$ up to $1 \mathrm{~m}$ and extrapolated to $2.5 \mathrm{~m}$ for mangrove stands of 664 different ages in the Matang Mangrove Forest Reserve, Malaysia. BD= bulk density. Values 665 are means \pm standard error of six plots.

\begin{tabular}{|c|c|c|c|c|c|}
\hline Depth (cm) & $\% \mathrm{OC}$ & $\% \mathrm{~N}$ & $\begin{array}{l}\text { BD } \\
\left(\mathrm{g} \mathrm{cm}^{-3}\right)\end{array}$ & $\begin{array}{l}\text { OC stock } \\
\left(\mathrm{Mg} \mathrm{C} \mathrm{ha-1)}^{-1}\right)\end{array}$ & $\begin{array}{l}\text { N stock } \\
\left(\mathrm{Mg} \mathrm{N} \mathrm{ha}^{-1}\right)\end{array}$ \\
\hline \multicolumn{6}{|l|}{ Clear-cut } \\
\hline $0-15$ & $6.3 \pm 0.5$ & $0.35 \pm 0.02$ & $0.46 \pm 0.03$ & $41.3 \pm 5.8$ & $2.41 \pm 0.26$ \\
\hline $15-30$ & $6.9 \pm 0.7$ & $0.37 \pm 0.02$ & $0.48 \pm 0.02$ & $51.2 \pm 4.1$ & $2.60 \pm 0.13$ \\
\hline $30-50$ & $11.0 \pm 0.9$ & $0.42 \pm 0.03$ & $0.41 \pm 0.02$ & $88.6 \pm 6.4$ & $3.50 \pm 0.23$ \\
\hline $50-100$ & $11.5 \pm 0.9$ & $0.44 \pm 0.02$ & $0.36 \pm 0.02$ & $204.2 \pm 20.7$ & $7.19 \pm 1.72$ \\
\hline Total: $0-100$ & & & & $385.2 \pm 72.6$ & $15.70 \pm 1.80$ \\
\hline Total: 0-250 & & & & $1,018 \pm 33.0$ & $33.0 \pm 6.05$ \\
\hline \multicolumn{6}{|l|}{5 years } \\
\hline $0-15$ & $8.8 \pm 1.5$ & $0.39 \pm 0.01$ & $0.47 \pm 0.03$ & $58.7 \pm 9.6$ & $2.58 \pm 0.25$ \\
\hline $15-30$ & $8.8 \pm 1.2$ & $0.40 \pm 0.01$ & $0.45 \pm 0.02$ & $61.3 \pm 5.1$ & $2.66 \pm 0.32$ \\
\hline $30-50$ & $11.8 \pm 2.1$ & $0.46 \pm 0.02$ & $0.42 \pm 0.02$ & $96.8 \pm 3.5$ & $3.64 \pm 0.17$ \\
\hline $50-100$ & $14.3 \pm 1.6$ & $0.47 \pm 0.04$ & $0.35 \pm 0.01$ & $244.0 \pm 6.2$ & $8.66 \pm 1.12$ \\
\hline Total: $0-100$ & & & & $460.8 \pm 14.8$ & $17.50 \pm 1.10$ \\
\hline Total: 0-250 & & & & $1,234 \pm 18.0$ & $40.1 \pm 4.06$ \\
\hline \multicolumn{6}{|l|}{15 years } \\
\hline $0-15$ & $16.8 \pm 1.7$ & $0.64 \pm 0.07$ & $0.30 \pm 0.03$ & $69.3 \pm 7.0$ & $2.63 \pm 0.28$ \\
\hline $15-30$ & $14.4 \pm 1.3$ & $0.58 \pm 0.08$ & $0.36 \pm 0.02$ & $79.3 \pm 3.7$ & $2.87 \pm 0.38$ \\
\hline $30-50$ & $17.0 \pm 1.0$ & $0.54 \pm 0.06$ & $0.33 \pm 0.02$ & $111.5 \pm 3.6$ & $3.81 \pm 0.03$ \\
\hline $50-100$ & $16.6 \pm 1.1$ & $0.54 \pm 0.04$ & $0.27 \pm 0.01$ & $223.1 \pm 14.3$ & $8.14 \pm 0.74$ \\
\hline Total: $0-100$ & & & & $483.2 \pm 22.1$ & $17.45 \pm 0.62$ \\
\hline Total: 0-250 & & & & $1,169 \pm 68.8$ & $40.51 \pm 3.19$ \\
\hline \multicolumn{6}{|l|}{30 years } \\
\hline $0-15$ & $18.1 \pm 1.6$ & $0.79 \pm 0.14$ & $0.26 \pm 0.02$ & $67.8 \pm 4.3$ & $2.80 \pm 0.32$ \\
\hline $15-30$ & $18.2 \pm 1.7$ & $0.66 \pm 0.04$ & $0.29 \pm 0.02$ & $77.4 \pm 5.1$ & $2.71 \pm 0.18$ \\
\hline $30-50$ & $17.2 \pm 1.7$ & $0.67 \pm 0.06$ & $0.31 \pm 0.02$ & $104.7 \pm 7.6$ & $3.97 \pm 0.37$ \\
\hline $50-100$ & $17.6 \pm 1.1$ & $0.61 \pm 0.06$ & $0.29 \pm 0.02$ & $247.6 \pm 8.9$ & $8.86 \pm 0.32$ \\
\hline Total: $0-100$ & & & & $497.5 \pm 21.5$ & $18.35 \pm 0.75$ \\
\hline Total: 0-250 & & & & $1,240 \pm 45.2$ & $44.95 \pm 1.72$ \\
\hline
\end{tabular}

\section{0 years}




$\begin{array}{llllll}0-15 & 11.1 \pm 1.9 & 0.47 \pm 0.10 & 0.41 \pm 0.06 & 56.5 \pm 5.2 & 2.95 \pm 0.19 \\ 15-30 & 10.5 \pm 2.2 & 0.45 \pm 0.11 & 0.41 \pm 0.04 & 54.9 \pm 6.3 & 2.42 \pm 0.12 \\ 30-50 & 10.3 \pm 1.9 & 0.44 \pm 0.09 & 0.47 \pm 0.03 & 79.5 \pm 12.3 & 4.21 \pm 0.61 \\ 50-100 & 13.5 \pm 2.2 & 0.53 \pm 0.07 & 0.42 \pm 0.02 & 252.3 \pm 25.3 & 9.69 \pm 0.78 \\ \text { Total: } 0-100 & & & & 454.3 \pm 21.3 & 19.26 \pm 0.83 \\ \text { Total: } 0-250 & & & & 1,187 \pm 100 & 48.5 \pm 4.23\end{array}$

\section{Reference (70 years)}

$\begin{array}{llllll}0-15 & 18.5 \pm 1.0 & 0.72 \pm 0.02 & 0.31 \pm 0.01 & 70.1 \pm 14.4 & 3.45 \pm 0.16 \\ 15-30 & 18.3 \pm 1.1 & 0.73 \pm 0.03 & 0.32 \pm 0.03 & 79.8 \pm 16.7 & 3.75 \pm 0.36 \\ 30-50 & 17.7 \pm 1.0 & 0.68 \pm 0.03 & 0.31 \pm 0.01 & 91.8 \pm 16.8 & 3.83 \pm 0.36 \\ 50-100 & 19.4 \pm 0.9 & 0.66 \pm 0.03 & 0.31 \pm 0.03 & 303.3 \pm 77.6 & 9.69 \pm 1.49 \\ \text { Total: } 0-100 & & & & 545.0 \pm 113.4 & 20.73 \pm 1.77 \\ \text { Total: } 0-250 & & & & 1,309 \pm 270 & 51.5 \pm 5.52\end{array}$

666

667 
668 Table 4. Ecosystem carbon and nitrogen stocks (soil up to $1 \mathrm{~m}$ in depth; $\mathrm{MgC} \mathrm{ha}^{-1}$ ) of

669 mangrove forests of different ages in Matang Mangrove Forest Reserve, Peninsular Malaysia.

670 Tree C stocks were obtained from Alongi et al. (2004), Goessens et al, (2014), and Hamid et

671 al. (2015).

\begin{tabular}{lcccccc}
\hline & Clear-cut & 5 yrs. & 15 yrs* & 30 yrs.** & 40 yrs. & 70 yrs. \\
\hline C stock & $385.2 \pm 72.6$ & $472.0 \pm 15.0$ & $679.5 \pm 22.2$ & $703.0 \pm 22.3$ & $630.3 \pm 24.5$ & $895.8 \pm 113.9$ \\
N stock & $15.7 \pm 1.8$ & $17.6 \pm 1.1$ & $19.6 \pm 0.6$ & $20.6 \pm 0.8$ & $21.2 \pm 0.8$ & $24.6 \pm 1.8$ \\
\hline & & & & &
\end{tabular}

$672 *$ After one round of thinning; ** after two rounds of thinning

673 

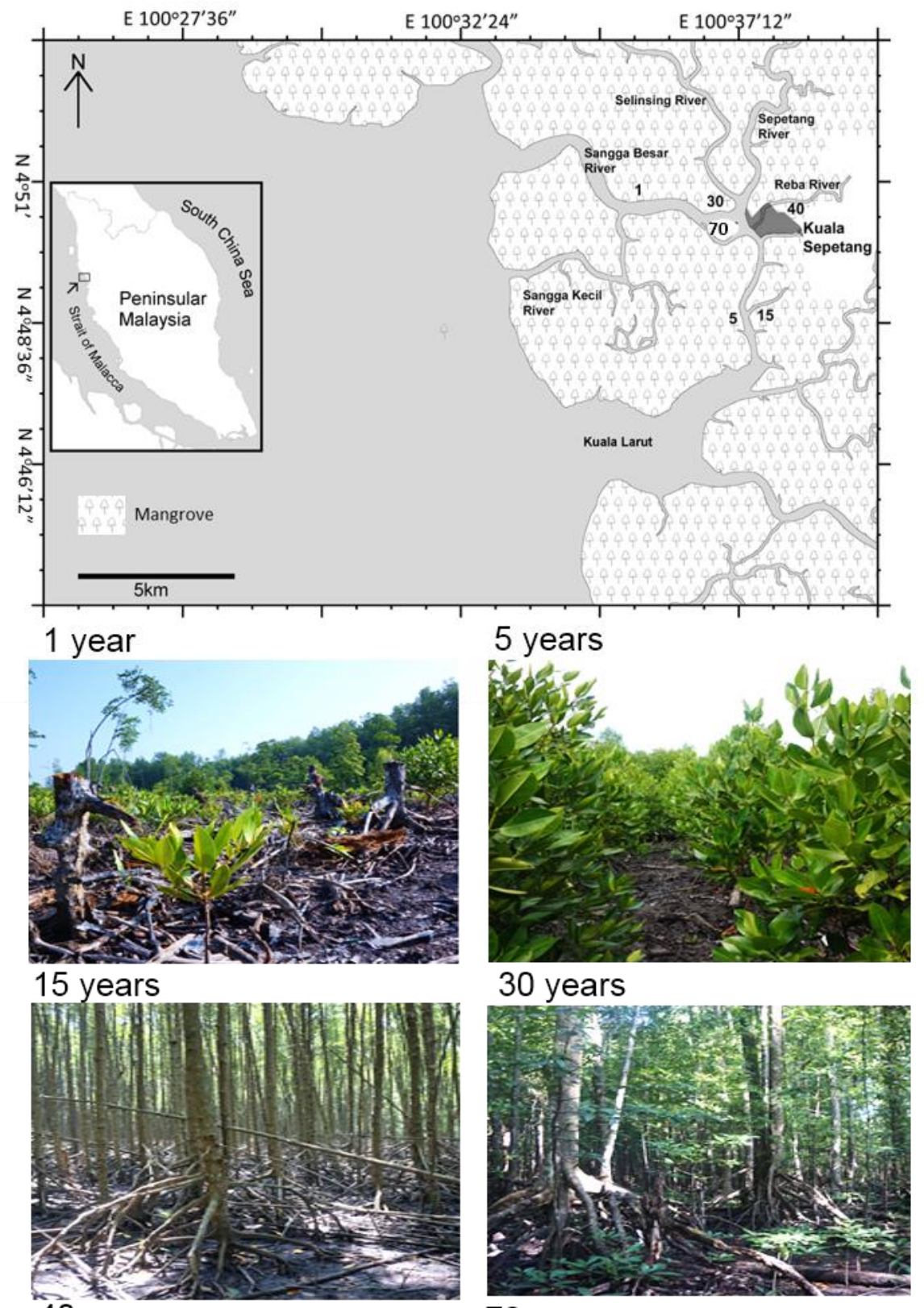

30 years

674

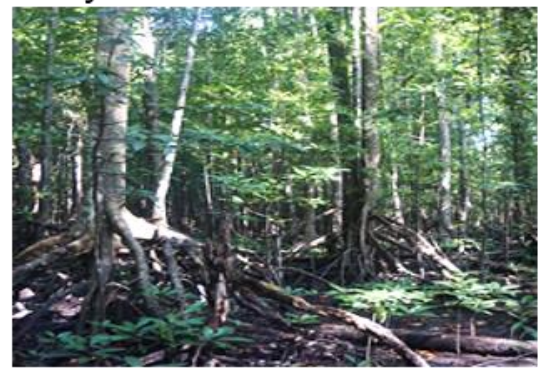

40 years

70 years
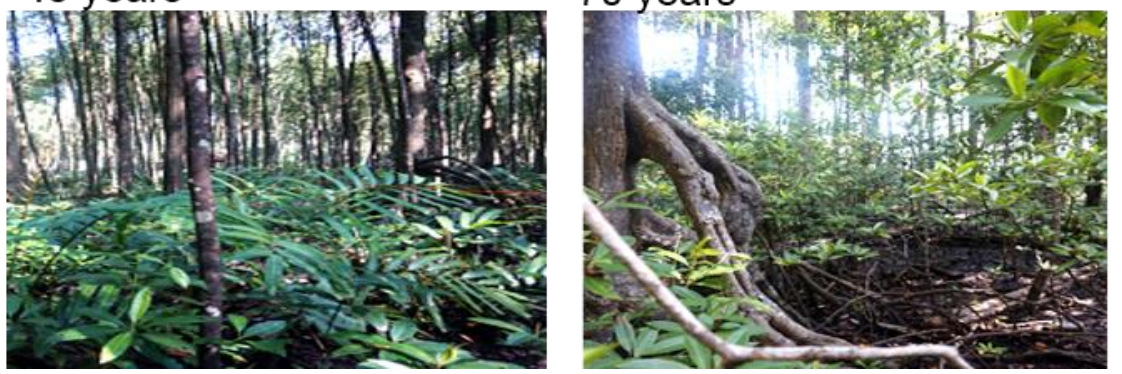

675 Fig. 1

676 

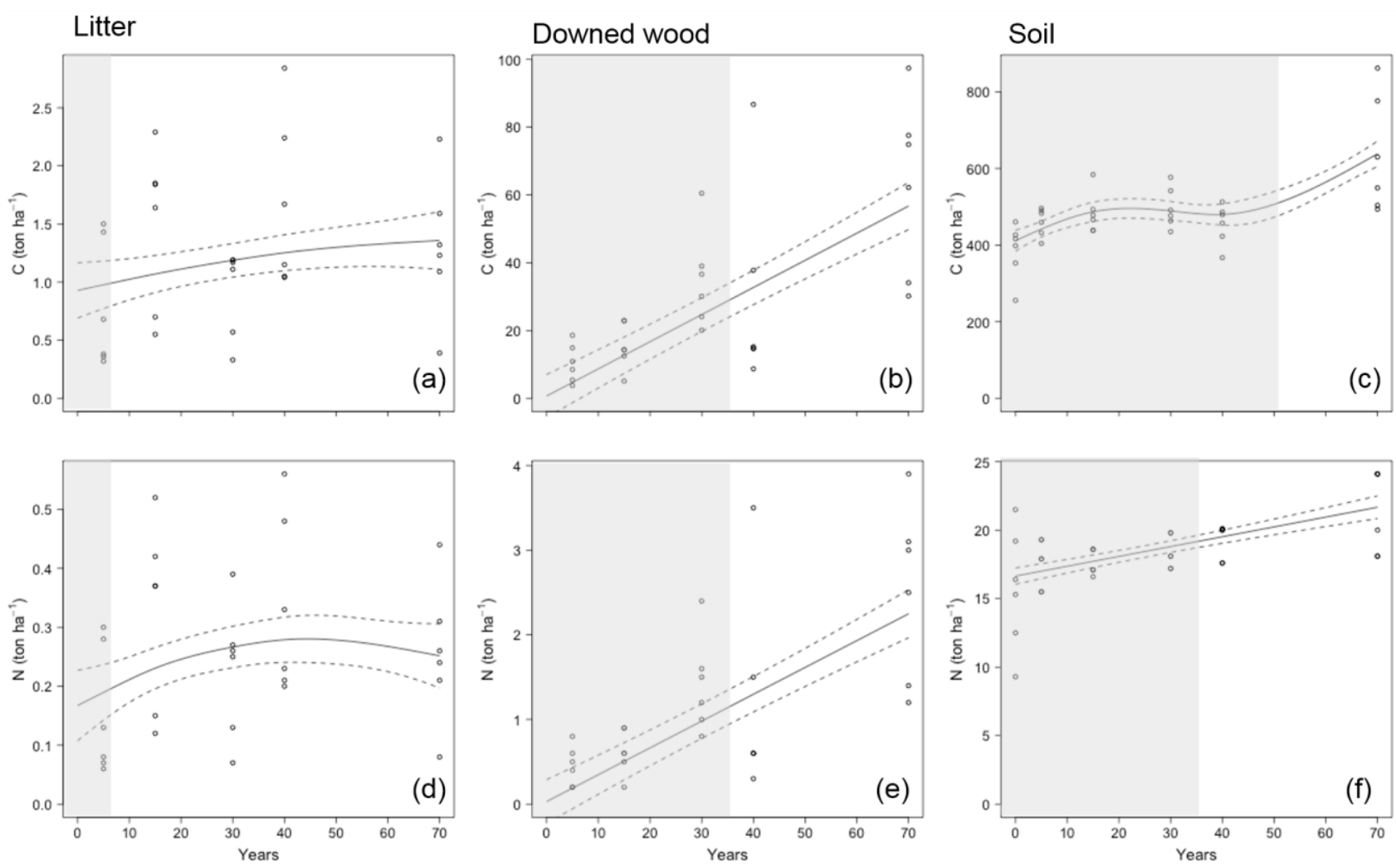

677

Fig. 2 

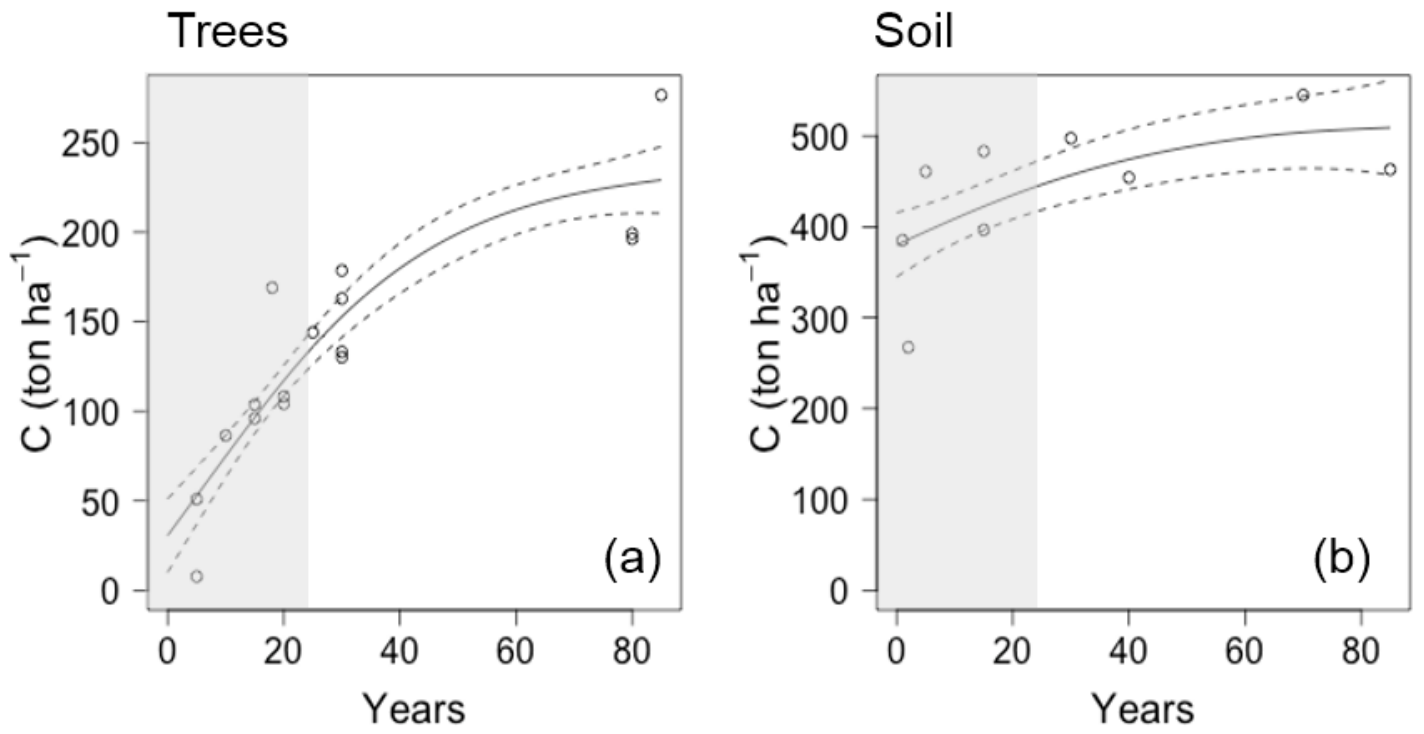

680

681 Fig. 3

682 


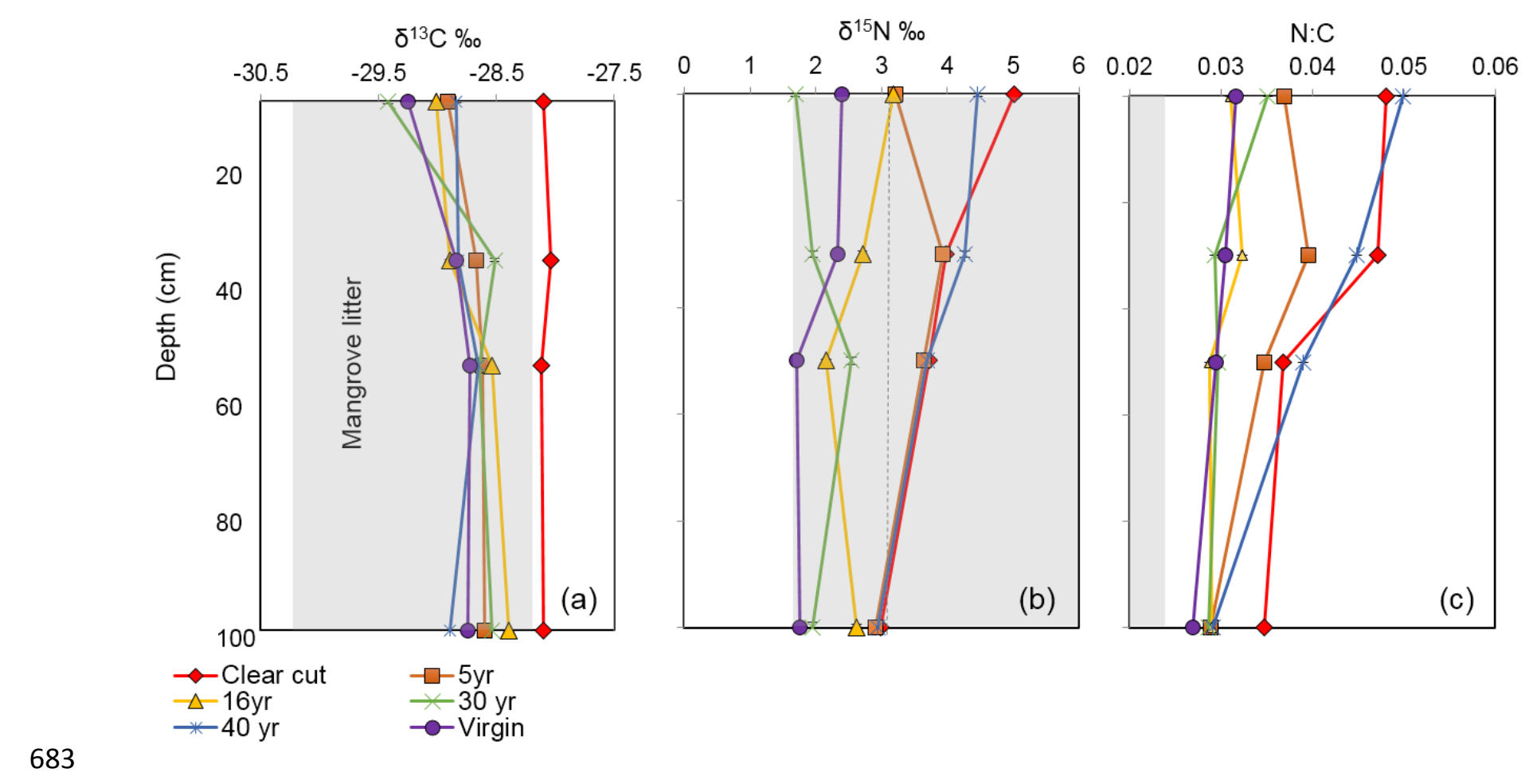

$684 \quad$ Fig. 4

685 


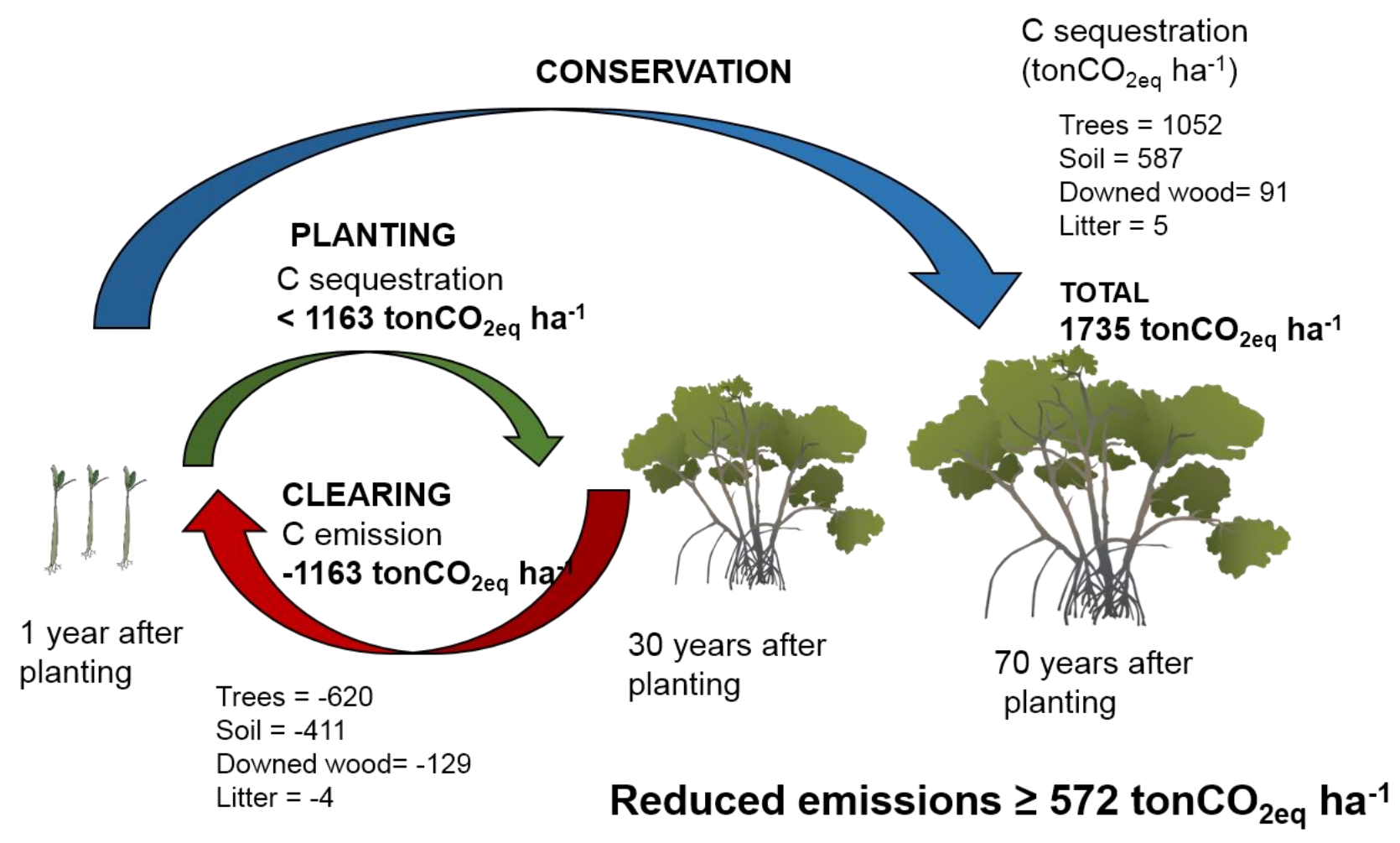

$687 \quad$ Fig. 5 